Article

\title{
Usage of Interface Management System in Adaptive Reuse of Buildings
}

\author{
Ekin Eray *, Benjamin Sanchez and Carl Haas \\ Department of Civil and Environmental Engineering, University of Waterloo, Waterloo, ON N2L 3G1, Canada; \\ b2sanchezandrade@uwaterloo.ca (B.S.); chaas@uwaterloo.ca (C.H.) \\ * Correspondence: eeray@uwaterloo.ca; Tel.: +1-519-888-4567
}

Received: 30 March 2019; Accepted: 29 April 2019; Published: 30 April 2019

\begin{abstract}
Adaptive reuse of buildings is considered a superior alternative for new construction in terms of sustainability and a disruptive practice in the current capital project delivery model for the renewal of today's built environment. In comparison to green-field construction projects, adaptive reuse projects require distinct stages, definition of interfaces, decision gates, and planning methods in order to secure the success of the building project. Unfortunately, little research has been done regarding establishing feasible systems for the planning, assessment, and management of adaptive reuse projects, leading to underperforming building projects outcomes. Interface management (IM) can improve renovation projects outcomes by defining appropriate ways to identify, record, monitor, and track project interfaces. IM has the potential of bringing cost and time benefits during adaptive reuse projects execution. The aim of this study is to develop a reference framework for implementing IM for adaptive reuse projects. First, the inefficiencies of redevelopment projects are explained inside of a circular economy (CE) context. Second, an ontology of IM for adaptive reuse projects is defined based on the current barriers to adaptive reuse and the most common interface problems in construction projects. Third, the defined ontology is expanded through a case study by showing examples of adaptive reuse barriers on a case project, and how IM could have been part of the solution for these problems. Finally, this study concludes with the suggestions on interface management systems (IMS) implementation for future adaptive reuse projects.
\end{abstract}

Keywords: adaptive reuse of buildings; interface management system; circular economy; interface problems in construction projects; barriers in adaptive reuse projects

\section{Introduction}

Due to environmental concerns, the global trend of the last three decades that proposes a shift from a resource-based economy towards a circular economy (CE) has begun to be accepted in the construction industry as not only socially and environmentally imperative, but as economically attractive due to emerging shortages of raw resources, such as water and crushed aggregates [1-3]. Adaptive reuse of buildings plays a key role in this transformation. It takes existing buildings that are obsolete, restores them, and in some cases, changes their use [4]. Adaptive reuse is considered superior to new construction in terms of sustainability and CE [5]. Among the schools of thought on sustainability and $C E$ for the current built environment, shared founding principles lie in the better management of resources, optimizing resource use with a life-cycle perspective, and material and energy waste minimization [1,2]. However, the current implementation of adaptive reuse relies on conventional intuitive planning procedures by professionals, leading to suboptimal results $[3,6]$. Therefore, there is a need to define better ways to identify, record, monitor, and track the project interfaces required for adaptive reuse of buildings. The conceptualization and execution phases of adaptive reuse projects involve the integration of emergent complex processes, such as supply chain management and logistics, 
and require numerous work packages distributed across multiple contractors. These emergent processes follow the transformation of the construction industry toward more sustainable development through the implementation of circular building principles, such as product recovery management (PRM), life cycle assessment (LCA), deconstruction planning, design for disassembly, design for adaptability, design for deconstruction, closed material loops, and dematerialization. Interface management systems (IMS), which focus on managing the communications, relationships, and deliverables between project stakeholders, are a potential solution for managing the complexities of adaptive reuse projects, through defining better ways to identify, record, monitor, and track the project interfaces.

In general, interface management (IM) is used in complex projects and executed by a large number of stakeholders who have different specializations, with many overlapping activities. Thus, adaptive reuse projects are a good class for IMS implementation. Establishing an appropriate IMS for adaptive reuse has the potential of enhancing the project outcomes by improving: (1) The confidence level to all the stakeholders regarding their scopes, roles, and responsibilities in the project, and (2) the efficiency of tracking deliverables by defining interface points between stakeholders. Also, to the authors' knowledge, this is the first time IMS is being introduced to an adaptive reuse project.

This article is an extension of work originally presented in CIB W78 Conference [7]. The outline of this article is as follows. In the second section, the concept of adaptive reuse and IM is explained. In the third section, the research methodology is presented, and then in the fourth section, the barriers in adaptive reuse projects are described. In the fifth section, common interface barriers in construction projects are presented and then compared with those of adaptive reuse described in the fourth section. In the sixth section, a case adaptive reuse project is explained, and then in the seventh section, a discussion and conclusion of this research are provided.

\section{Background}

\subsection{Adaptive Reuse of Buildings in a Circular Economy}

Due to growing concern for the environment in many countries, designing for sustainability and a $\mathrm{CE}$ are becoming a requirement rather than just a desirable characteristic for products and services in the construction industry $[1,8,9]$. The main reasons for this global trend are that an enormous proportion of the materials extracted in human history are in today's built environment, and this materials stock is going to keep increasing considerably in the coming decades $[10,11]$. Besides, the price of raw materials extraction is increasing as are the negative environmental impacts due to natural constraints of dilute and distant stocks of ores and resources [8], as well as the excessive waste generation from the construction industry on a global scale $[10,12]$. To remedy this situation, the construction industry is implementing designs and systems with improved long-term life-cycle performance. The main objective of these designs and systems is to consider the circular design principles of repair, maintain, reuse/redistribute, and recycle/refurbish/remanufacture in order to minimize (or close) material and energy loops [13]. A closed-loop material cycle in construction can be defined as recovering construction materials and building elements from old buildings and reusing them through natural or industrial processes [14]. Several studies have recognized, in the end of life (EoL) stage of buildings, the opportunity of minimizing (or closing) material and energy loops through product recovery management (PRM) [8,14-17]. PRM has the purpose of recovering as much of the economic and the ecological value of a product and its components as possible [16]. Also, several studies have demonstrated that the applications of green design methods, such as design for disassembly, design for deconstruction, disassembly planning, and life cycle assessment (LCA), in the building industry represent a way to fully exploit the life cycle expectancy of buildings and building materials and components [17-23].

Adaptive reuse of buildings is considered by most practitioners as a superior alternative to new construction in terms of sustainability and CE $[5,24,25]$. The correct implementation of adaptive reuse has the potential of improving the financial, environmental, and social performance of existing 
buildings. It takes existing buildings that are obsolete, restores them, and in some cases, changes their use $[4,26]$. Adaptive reuse is a complex process where green design methods can be implemented in order to improve the project outcomes.

The potential benefits of adaptive reuse rely on the fact that it is possible to take away components from an obsolete building and then repair, reuse, remanufacture, or recycle them. In this matter, some of the most important green design methods include design for disassembly, design for maintainability and serviceability, design for reuse, design for remanufacturing, and design for recyclability [27]. For existing assets, complete designing for disassembly is not possible, and the process is reduced to planning for disassembly. Planning for disassembly plays an important role in the redevelopment design process where the selective deconstruction planning, as well as the deconstruction methods to recover components, have to be performed in an efficient way. The objectives are to reduce building costs of deconstruction activities and to increase the number of building component life cycles. If the disassembly planning is too complex or time-consuming, the associated economic and environmental costs could be higher than new construction. This field has been studied in the manufacturing industry since the last decade, concluding that disassembly planning can reduce the time and cost associated with disassembling products [27].

The processes associated with the project management of renovation projects are diverse and dynamic. The difficulty lies in all the different aspects that have to be taken into account, such as the physical integrity of the building, economic issues, functionality, technological retrofits, social impact, and legal and political issues $[10,28]$. These aspects could vary considerably from building to building. The transition from the current linear economic model towards a circular one, implies a radical rearrangement of: (1) The value chain of the built environment [29-32], (2) the ownership models for buildings [1], (3) the business models for profitability in the construction industry [9,33], (4) the engagement of stakeholders in all the levels of society, e.g., government, suppliers, builders, and owners [2], and (5) the technical protocols and the methodologies for sustainable construction [3]. For these reasons, little research has been done regarding establishing feasible systems for the planning, assessment [3,34], and management [35,36] of adaptive reuse projects. Some authors stress that intuition and experience are the only guides in making decisions about adaptive reuse [37]. However, there is enough evidence to suggest that the inefficiencies in the process of adaptive reuse will be addressed in the coming years in order to move towards a more sustainable development in the construction industry.

\subsection{The Concept of Interface Management}

There are several definitions and classifications for "interfaces" in the literature. According to the Construction Industry Institute (CII)'s interface management guideline, "interface" is defined as "a soft and/or hard contact point between two interdependent interface stakeholders", and "interface management" is defined as "the management of communications, relationships, and deliverables among two or more interface stakeholders" [38].

When a project is divided into several subprojects undertaken by different organizations, many interfaces occur between these organizations [39-41]. There are several different interface classifications in the literature. In this paper, interfaces in the adaptive reuse projects will be studied under three main categories: Physical, organizational, and contractual interfaces. Physical interfaces are the physical connections between two or more elements or components in a project, such as two connected pipes built by two different stakeholders. Foundations and columns, columns and walls, walls and beams, as well as beams and slabs also create physical interfaces. This type of interface is generally clearly and visually apparent in a project. Contractual interfaces can be defined as connections between interface stakeholders through contractual agreement. This type of interface can also be related with a physical interface. For example, work packages in the construction supply chain management system would create contractual interfaces between stakeholders, and those interfaces can be physical interfaces as well. Work packages are one of the efficient ways to complete the projects. However, clear scope 
definition and contract agreement should be set prior to execution. Interface management plays critical roles to establishing a seamless project plan. Organizational interfaces are the interactions between several interface stakeholders who are involved in the project. These interfaces include all the relationships and connections between any individual and any parties involved in the project throughout the project life cycle [41,42]. Other classifications for interfaces including soft and hard interfaces, time interface, geographical interface, and technical interface can be also found in the literature [39].

A typical interface management system (IMS) would consist of four main components: Interface stakeholders, interface points (IPs), interface agreements (IAs), and interface agreement deliverables (IADs). Practically speaking, interface agreements are the documents that record communications and agreements between two interface stakeholders over interface points, and interface agreement deliverables are a combination of the documents that are required to fulfill related interface agreements such as documents that show the tasks and activities completed, schedules and timelines, drawings, quotations, and estimations. Generally, an IMS may include dozens if not hundreds of IPs, each IP may include multiple IAs, and each IA may include various types of IADs. Therefore, there could be numerous IADs in a system [41,43]. A simplified IMS hierarchy can be seen on Figure 1.

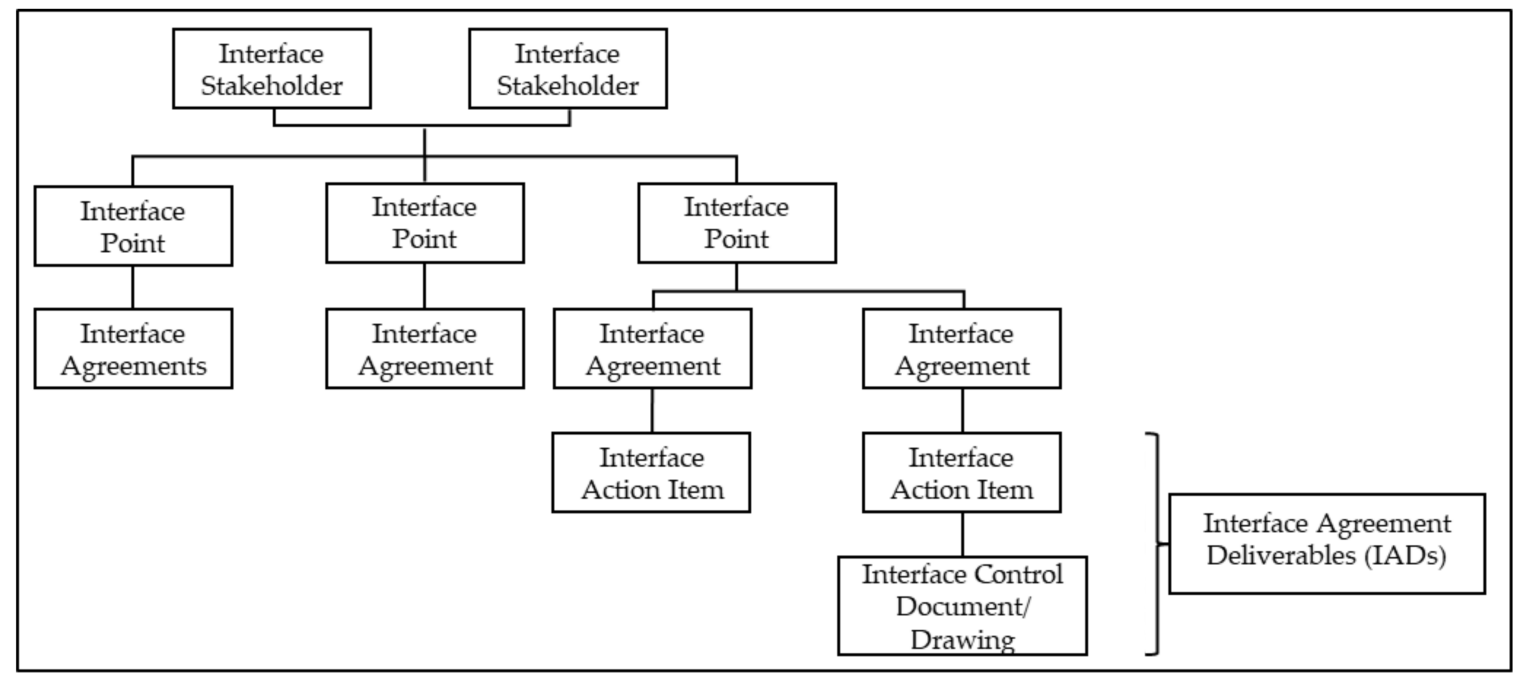

Figure 1. A simplified interface management system hierarchy.

Recording and managing interface points (IPs), interface agreements (IAs), and interface agreement deliverables (IADs) make up the core structure of an interface management system (IMS). The fundamental data of an IP that should be recorded include reference number, title, description, category, involved stakeholders and their responsibilities, creation and approval dates, and the status of the IP. As it is illustrated in Figure 1, there can be several IAs related with an IP. Therefore, it is also recommended to register and track IAs by recording description of IAD, creation date of IA, need date, forecasted date, delivery date, and closing date $[38,43]$. These are the examples of metadata required.

An increasing number of studies on the definitions of IMS, interface problems in different types of construction projects, and web-based IMS platforms, can be found in the literature. The concept of IM was first introduced as a subset of system engineering in 1960s and the first applications of IM can be seen in the aerospace industry [38]. One of the early works on defining the need for IMS in construction projects, particularly for the cladding interfaces while building a façade, was done by Pavitt and Gibb (2003). After defining the need, they also provided a software system that helps project stakeholders to manage interfaces in their projects [42]. In 2006, Chua and Godinot introduced the concept of the work breakdown structure (WBS) matrix to improve IMS in construction projects [39]. In 2008, Chen et al. investigated the causes of the interface problems that occur at offshore, commercial, and residential construction projects, with a multi-perspective approach [44]. Another IMS platform 
was developed by Lin (2013) to connect project participants over a web-based system and manage interface problems during the construction phase [45]. In 2014, CII introduced the IM implementation guide where definitions of IMS elements, and effective IM practices that can be applied broadly on different type of construction projects, are explained [38]. In 2015, two different web-based IMS are introduced. Ju and Ding (2015) proposed an integrated interface model to improve IMS. In this model they changed traditional IMS to a more standardized and structured web based IM format [46]. Lin (2015) proposed a web based IMS that integrates the three dimensional interface maps to a Building Information Modeling (BIM) approach to improve physical interface information sharing and tracking during the construction phase of building projects [47]. Eray et al. (2017) also introduced a framework on integrating IM and BIM systems by connecting related IPs and IAs to related BIM elements on 3-D models [48].

IMS is applicable within a wide range of projects and different sectors, however the benefits of IMS are more visible when the complexity of a project is high. Complex construction projects, where the project is divided into several work packages undertaken by various stakeholders and project teams, have higher dollar values and more technical and organizational complexity that would benefit more from the capabilities of IMS [43]. Adaptive reuse projects are a good example for complex construction projects, since these projects mostly include large numbers of project stakeholders working in close contact, overlapping construction activities, and uncertainties and risk in all phases of the project. Adopting IMS in adaptive reuse projects would create effective coordination and communications among project stakeholders and also would create real-time tracking on interface deliverables.

In recent years, the usage of IMS in construction industry has increased. Even though IMS was introduced in the 1960s, it was not widely used in construction projects, due to the lack of necessary technological infrastructure. Also, not having a common understanding of IM and its components was another reason for not adopting IMS extensively in the construction industry. Today, more engineering and construction projects have adopted IM because of technological improvements on communication and information systems, and common definitions of IMS and its elements [41,43,48-51].

\section{Research Methodology}

This paper is being carried out by the following five steps illustrated on Figure 2. First, an extensive literature review on adaptive reuse projects is conducted and a list of barriers in these projects are defined. Second, an extensive literature review on interface problems in construction projects is conducted. Third, interface problems that are found in the literature are compared and paired with defined barriers in adaptive reuse projects. Fourth, these paired adaptive reuse barriers and interface problems are explained on a case study. Last, how these problems can be solved and how interface management system usage can present a solution for improving the performance of adaptive reuse projects is discussed.

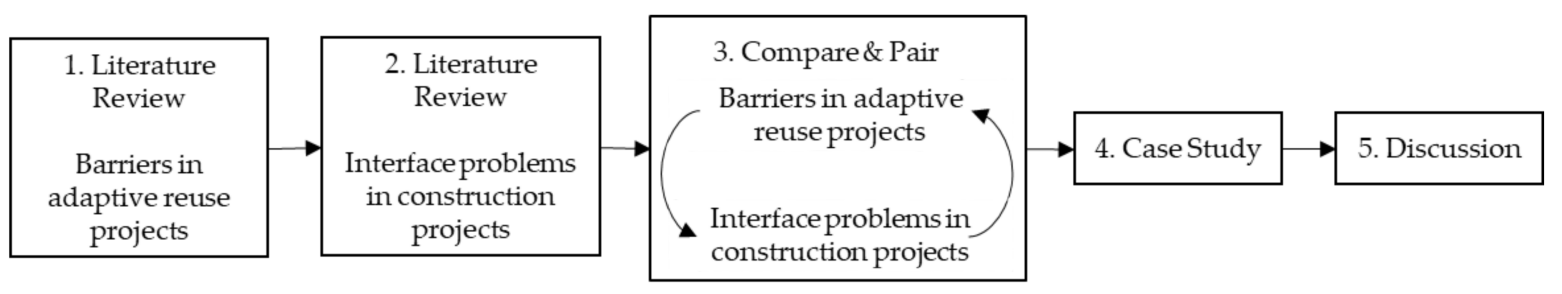

Figure 2. The methodology steps of this paper.

\section{Barriers in Adaptive Reuse Projects}

Although adaptive reuse has many economic, social, and environmental benefits, projects face many challenges and barriers during the project life cycle, especially when the project involves heritage buildings. Hein and Houck (2008) conducted research regarding construction challenges in adaptive reuse of historical buildings in Europe, where adaptive reuse is widely practiced to preserve 
these historical buildings [52]. The main construction challenges explained with examples from four significant European adaptive reuse projects are: Compliance with building codes and preserving laws; temporary structural support of preserved components; expectations of modern tenants, such as new electrical, plumbing, HVAC systems etc.; toxin removal; modification on the structural integrity of the building, such as modification of the structural skeleton, foundation system, or roof system; and site access problems [52].

In 2016, Conejos et al. identified fourteen barriers that occur in building type adaptive reuse projects. These barriers include building codes and regulations, legal constraints, physical restrictions, high remediation costs and construction delays, complexity and technical difficulties, inaccuracy of information and drawings, maintenance, availability of materials and lack of skilled tradesmen, limited response to sustainability agenda, inertia of production and development criteria, classification change, economic considerations, social considerations, commercial risk and uncertainty, and financial and technical perceptions [53]. In this paper, these barriers defined by Conejos et al. will be used as base points for defining adaptive reuse project problems. In addition to these barriers, "Management problems" is added to this list as the fifteenth barrier.

More than half of the barriers defined by Conejos et al. (2016) are due to physical interfaces between project participants, such as compliance with building codes, physical constraints, complexity, and technical difficulties [53]. These barriers are also a subject of interface problems in any construction projects and can be managed by creating IPs and IAs between project participants in the early phases of the projects, such as the conceptual design and detailed design phases. In the case study presented in this paper, the concept and how IM system can be a solution to some of these problems are explained.

\section{Common Interface Problems in Construction Projects}

In the literature, interface problems in construction projects are studied mainly under varying constraints, such as limiting the study to only two parties involved in a project, or limiting the project type to a specific construction category, to a specific phase in the project life cycle, to a country or region, or to a specific interface type. In order to define the connections between common interface problems and adaptive reuse barriers, different types of articles addressing interface problems in construction projects were studied.

Interface problems between two main parties in construction projects, such as interface problems between owners and contractors, designers and contractors, contractors and subcontractors, owners and maintenance contractors, and owners and designers, have been studied [54-60]. These studies were generalized by Al-Hammad in 2000 [61]. In the aforementioned research, which will be called Paper-1 from this point on, nineteen common interface problems among various construction parties were defined and classified into four general categories: Financial, contract and specifications, environmental, and other common interface problems.

Interface problems that could exist during either the design phase, construction phase, or during both (i.e., design-construction interface) can be found in the past literature [62-65]. Many items on the list that contain design-construction interface problems are extracted from different papers. For example, Sha'ar et al. (2016), in a study which will be called Paper-2 from this point on, defined 60 design-construction interface problems and categorized them into five groups: Owner-related, consultant-related, contractor-related, project-related, and external causes, in order to identify the causes of these problems in large building construction projects in Palestine [63]. After defining design-construction interface problems, Sha'ar et al. (2016) conducted a survey among construction professionals in Palestine and analyzed responses from 30 consultants and 34 contractors. According to the survey results, the consultant related causes were ranked as the most significant category while the top three significant problems were found as: (1) Unstable client requirements; (2) lack of proper coordination between various disciplines of the design team; (3) awarding the contract to the lowest price regardless of the quality of service. Another similar study on design-construction interface problems was published by Al Mousli and El-Sayegeh in 2016. Al Mousli and El-Sayegeh (2016), 
in a study which will be called Paper-3 from this point on, investigated design-construction interface problems that occur in United Arab Emirates (UAE) construction industry, which is unique due to the trend of mega construction projects in the region. Al Mousli and El-Sayegeh (2016) defined a list of 22 design-construction interface problems and conducted a survey among construction professionals in the UAE. Survey results showed that the main design-construction interface problems were related with the lack of coordination and management throughout the project life cycle [64].

In order to find connections between adaptive reuse barriers and interface problems in the construction industry, the list explained in Section 4 of this paper was compared with the interface problems provided in Paper-1, Paper-2, and Paper-3, respectively. Comparisons were made on the basis of ideas rather than words, which means that "Inaccuracy of information and drawings" and "Mistakes and discrepancies in design documents" were accepted as being the same even though they are explained in different words. The result of these comparisons is presented in Table 1.

Many of the defined barriers in Table 1 are related with interface points between project participants. For example, any barrier related with physical restrictions in the project would be related with physical interface points between project participants. For the purpose of this research paper, these defined barriers were also categorized into four interface groups, namely physical interface $(\mathrm{P})$, organizational interface (O), contractual interface (C), and out of scope (S) group. The categories of the listed barriers are shown in the second column of Table 1.

Table 1. The comparison of adaptive reuse barriers to common interface problems.

\begin{tabular}{cccccc}
\hline No & Type & Adaptive Reuse Challenges & Paper-1 & Paper-2 & Paper-3 \\
\hline 1 & P,C & Building codes and regulations, and legal constraints & $\mathrm{x}$ & $\mathrm{x}$ & $\mathrm{x}$ \\
2 & $\mathrm{P}$ & Physical restrictions & - & $\mathrm{x}$ & $\mathrm{x}$ \\
3 & $\mathrm{P}$ & High remediation costs and construction delays & $\mathrm{x}$ & - & - \\
4 & $\mathrm{P}$ & Complexity and technical difficulties & $\mathrm{x}$ & $\mathrm{x}$ & $\mathrm{x}$ \\
5 & $\mathrm{P}, \mathrm{C}$ & Inaccuracy of information and drawings & $\mathrm{x}$ & $\mathrm{x}$ & $\mathrm{x}$ \\
6 & $\mathrm{P}$ & Maintenance & - & - & - \\
7 & $\mathrm{O}$ & Availability of materials and lack of skilled tradesmen & $\mathrm{x}$ & $\mathrm{x}$ & $\mathrm{x}$ \\
8 & $\mathrm{O}$ & Limited response to sustainability agenda & - & - & - \\
9 & $\mathrm{O}$ & Inertia of production and development criteria & - & - & - \\
10 & $\mathrm{C}$ & Classification change & $\mathrm{x}$ & $\mathrm{x}$ & $\mathrm{x}$ \\
11 & $\mathrm{~S}$ & Economic considerations & $\mathrm{x}$ & $\mathrm{x}$ & - \\
12 & $\mathrm{~S}$ & Social considerations & - & $\mathrm{x}$ & - \\
13 & $\mathrm{~S}$ & Commercial risk and uncertainty & $\mathrm{x}$ & $\mathrm{x}$ & - \\
14 & $\mathrm{~S}$ & Financial and technical perceptions & $\mathrm{x}$ & $\mathrm{x}$ & $\mathrm{x}$ \\
15 & $\mathrm{P}, \mathrm{O}, \mathrm{C}$ & Management problems & &
\end{tabular}

\section{Case Study}

The case adaptive reuse project subjected to this research is a mid-20th century building built with a modern architectural style. The building is located in the Region of Waterloo, Ontario, Canada. In the past, this region was a predominantly manufacturing industrial cluster. Nowadays, the economy of the region has diversified and includes new high-value economic clusters. It is known for its high concentration of tech companies. Thus, it has often been referred to as "Canada's Silicon Valley". Due to this economic transformation, in the whole region, several factories have been through adaptive reuse into new buildings with new purposes, such as office and lab buildings, upscale lofts, and residences. The project is a four-story structure with a basement and has a shape similar to a boomerang with a footprint area of $1233 \mathrm{~m}^{2}$ and $5341 \mathrm{~m}^{2}$ gross floor area. The primary structural system of the building is a steel frame. The original building was built in 1964 and was redeveloped using adaptive reuse from 2014 to 2015. According to the heritage report of the case project, the building was classified as non-designated property of cultural heritage value. All of the building's subsystems had modifications which were primarily due to the increment of loads, the complete rearrangement of the floor layouts, and the expansion of the gross floor area by $487 \mathrm{~m}^{2}$. One of the changes included the infilling of two large double-height rooms. The redeveloped project has been rated as a Leadership in Energy 
and Environmental Design (LEED) Gold Building. The adaptive reuse process of the case project is illustrated in Figure 3.

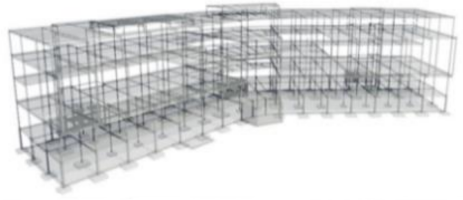

Adaptation Planning $\longrightarrow$

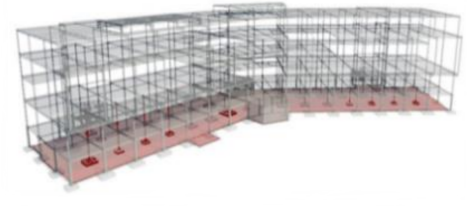

Selective Disassembly \& Demolition

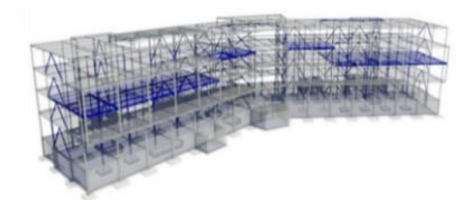

Renovations

Figure 3. Adaptive reuse process of the case project.

The aim of this case study is to present interface point examples for selected adaptive reuse barriers and interface problems documented during the realization of the case project. In order to define the IPs in the project, project stakeholders were first investigated. According to the project documents, there were 17 stakeholders in this project and each of them were responsible for different parts of the project. Project stakeholders are presented in Table 2 with their codes. It is important to highlight the main limitations of the presented study. It was not possible to develop the case study with more specific data and statistical analysis (time, money, and material savings) due to the lack of information and documentation provided by the architectural firm. Therefore, the conclusions are rational conjectures based on the professional judgement of the authors emerging from the analysis of the available documentation. Future investigations are required to collect statistical data and to develop a more extensive case study.

Table 2. Project stakeholders in the case project.

\begin{tabular}{|c|c|c|c|c|c|}
\hline No & Scope Package Name & Code & No & Scope Package Name & Code \\
\hline 1 & Owner & OWN & 10 & Geotechnical Investigation * & GEO \\
\hline 2 & Architectural firm * (designer) & ARC & 11 & Hazardous Building Materials* & HBM \\
\hline 3 & Structural * & STR & 12 & Asbestos Abatement Contractor & $\mathrm{AAC}$ \\
\hline 4 & Mechanical * & MEC & 13 & Finishing Hardware Contractor & FHC \\
\hline 5 & Electrical * & ELE & 14 & General Contractor & GC \\
\hline 6 & Landscape * & LND & 15 & Mechanical Contractor & MECC \\
\hline 7 & Civil * & CVL & 16 & Electrical Contractor & ELEC \\
\hline 8 & Sustainable Design (LEED) * & SD & 17 & Roofing Contractor & $\mathrm{RC}$ \\
\hline 9 & Vertical Transportation* & VT & & & \\
\hline
\end{tabular}

After determining the project stakeholders and their responsibilities, interface points between these stakeholders were investigated. The documentation of the case study showed many critical IPs between the parties, including the assurance of the accuracy of the technical information, drawings, and specifications for the adaptive reuse of the building. The main IPs detected were between the consultants and the designer during the planning stage, as well as between the contractors and the consultants during the execution of the project.

\subsection{Physical Interfaces}

As it is presented in Table 1, four of the physical interface-related adaptive reuse barriers, "Building codes and regulations, and legal constraints", "Complexity and technical difficulties", "Inaccuracy of information and drawings", and "Management problems", are commonly mentioned as interface problems in the articles studied. When the documents of the case project were investigated, it was found that there was continuous feedback between the consultants and the architectural firm, as well as continuous corrections of the structural, civil, mechanical, and electrical final designs through addendums to the original project. The contract specified reiteratively that the subcontractors should verify all dimensions and existing conditions on site and should report all discrepancies to the consultant 
before proceeding with the work. Also, the contract emphasized that the drawings (civil, landscape, structural, mechanical, electrical drawings, and geotechnical and acoustical reports) should be read in conjunction with one another. All of these documents are examples of "inaccuracy of information and drawing" related interface problems.

Additionally, the fulfillment of the legal constraints related to the adaptive reuse of a building is a point of high interaction between different project parties. In these points of interaction, the responsibilities of the consultants are to ensure a final design according to the current normativity and to report any change in the pertinent timing. Because the consultants have to be aware of the existing conditions of the building asset, they have to develop an accurate and detailed inspection of the site and then develop accurate reports, drawings, and building specifications for the other parties. It is worth highlighting that for the projects that involve the restoration of a building asset, it is recommended to create these physical interface points during the planning stage. For new constructions, it is not necessary because there is no existing asset to inspect.

Table 3 shows seven IP examples that can be created between the consultants and the architectural firm, as well as the normativity established for the case study under analysis. Additionally, for the construction phase, the interface points presented in the table would be the same, but the communication of them should be between the contractors as interfacing party and the architectural firm as the lead party. Ideally, these interface points should be created and managed from the beginning in order to secure the final accuracy, quality, and veracity of the technical information, drawings, and specifications.

Table 3. Interface point examples related with physical adaptive reuse barriers.

\begin{tabular}{ccccc}
\hline Lead Party & Interfacing Party & IP Type & IP Title & Interface Agreements topics \\
\hline ARC & GEO & $\mathrm{P}$ & Geotechnical Investigation & The due date \\
ARC & HBM & $\mathrm{P}$ & Asbestos Removal & Construction methodology \\
ARC & STR & $\mathrm{P}$ & Column renovation & Loads that need to be considered \\
ARC & STC & $\mathrm{P}$ & Foundation Footings & Sizes and types of new footings \\
ARC & MEC & $\mathrm{P}$ & Duct design & Sizes of the ducts required \\
ARC & ELE & $\mathrm{P}$ & Technical room & Electrical plans, voltages \\
ARC & VT & $\mathrm{P}$ & Elevator shaft & Dimensions of the elevator shaft \\
ARC & GEO & $\mathrm{P}$ & Geotechnical Investigation & The due date \\
\hline
\end{tabular}

\subsection{Contractual and Organizational Interfaces}

In construction projects, contractual and organizational interface points also exist along with physical interface points. The main barrier in the adaptive reuse case project was related with management problems, which are classified as physical, contractual, and organizational interfaces in Table 1. The case project ended up with cost and time overruns since it had a complex structure of project stakeholders where roles and responsibilities were unclear. According to project documentation, the general contractor was responsible for coordination of all the subcontractors, and also responsible for setting and chairing coordination meetings among owner, consultant, contractor, subcontractors, and key material suppliers, which creates organizational interfaces between parties. While the general contractor's main role is to establish contracts, its strength is to arrange and manage subcontractors. Most of the barriers and interface problems occurred due to the lack of communication between subcontractors and the general contractor. Lack of interorganizational structures and improper approval line created confusion between stakeholders and rework.

Project documentations also show that the architectural firm was responsible for both the design and management of the project which include managing different types of consultants and contractors. For example, in a contract between an architectural firm and one of the contractors, it was written that "The Consultant's review of shop drawings does not relieve the Contractor of their responsibility to review all information pertaining to: 1 . detail design; 2 . dimensions; 3 . information pertaining to fabrication processes; 4 . techniques of construction and installation; 5 . coordination of the work of Subcontractors." While this statement allocates responsibilities to the contractor, it also creates contractual interface points which are also subject to physical interface points. 


\section{Conclusions}

In this paper, a reference framework for implementing Interface Management System (IMS) for an adaptive reuse project is presented. In order to achieve this aim, first, the concept of adaptive reuse of buildings in the circular economy context and the concept of IM was explained. Then, a literature review on main barriers on adaptive reuse projects and common interface problems in construction projects was conducted. Discovered barriers and problems were compared, and paired, and finally categorized into four interface groups, namely physical interface $(\mathrm{P})$, organizational interface $(\mathrm{O})$, contractual interface (C), and out of scope (S) group. These problems were briefly explained in the case study section by providing examples of "inaccuracy of information and drawings" related barriers, and "management problems" related barriers from the case project.

While investigating the case project documentation, it was also found that "management problems" was the main barrier category in this project. Project organization structures of the stakeholders were highly complex, and roles and responsibilities were unclear. These problems were briefly mentioned in the case study. One way to solve these problems is assigning an interface manager to the project and setting an IMS where interface points (IPs) between project stakeholders can be defined, so that interface agreements (IAs) and interface agreement deliverables (IADs) can be tracked. Interface management is an iterative process and setting an IMS for such complex projects would require collaboration and commitment of all project stakeholders through the project life cycle. Setting an IMS would also help managing documents, communications, and relationships between project stakeholders, which were missing in the case study.

Assigning an interface manager who has a general knowledge of the project and high communication skills and setting and IMS would be the first step of solving the missing connection between these groups. When there is a problem, interface manager will be able to assign the right tasks to right stakeholders. By setting the IMS in the early phases of a complex project, the roles and responsibilities of each stakeholder can be defined in advance, and IPs-, IAs-, and IADs-related communications can be more structured.

In conclusion, this paper contributes in demonstrating that most of the barriers on the adaptive reuse projects investigated in the literature can be paired with common interface problems in construction projects. Therefore, depending on the project size, either a shared spreadsheet that shows IPs and related agreements between stakeholders, or a more sophisticated IMS software usage is recommended for adaptive reuse projects. Establishing an appropriate IMS would give more certainty to all parties regarding their scopes, roles, and responsibilities in the project. Also, when IPs between stakeholders are defined early in the project, the stakeholders can clarify the work packages, and deliverables can be tracked more efficiently. The workflow can also be streamlined as clear agreements between stakeholders are established. In this way, more stakeholders in complex adaptive reuse projects will feel comfortable being involved.

Author Contributions: Conceptualization, E.E., B.S. and C.H.; Investigation, E.E. and B.S.; Methodology, E.E. and B.S.; Supervision, C.H.; Writing - original draft, E.E. and B.S.; Writing - review \& editing, C.H.

Funding: This research received no external funding.

Conflicts of Interest: The authors declare no conflicts of interest.

\section{References}

1. Pomponi, F.; Moncaster, A. Circular economy for the built environment: A research framework. J. Clean. Prod. 2017, 143, 710-718. [CrossRef]

2. Geissdoerfer, M.; Savaget, P.; Bocken, N.M.P.; Hultink, E.J. The Circular Economy-A new sustainability paradigm? J. Clean. Prod. 2017, 143, 757-768. [CrossRef]

3. Sanchez, B.; Haas, C. Capital project planning for a circular economy. Constr. Manag. Econ. 2018, 36, 303-312. [CrossRef] 
4. Langston, C.; Wong, F.K.W.; Hui, E.C.M.; Shen, L.-Y. Strategic assessment of building adaptive reuse opportunities in Hong Kong. Build. Environ. 2008, 43, 1709-1718. [CrossRef]

5. Conejos, S.; Langston, C.; Smith, J. Enhancing sustainability through designing for adaptive reuse from the outset. Facilities 2015, 33, 531-552. [CrossRef]

6. Mohamed, R.; Boyle, R.; Yang, A.Y.; Tangari, J. Adaptive reuse: A review and analysis of its relationship to the 3 Es of sustainability. Facilities 2017, 35, 138-154. [CrossRef]

7. Eray, E.; Sanchez, B.; Kang, S.; Haas, C. Usage of Interface Management in Adaptive Reuse of Buildings. In Advances in Informatics and Computing in Civil and Construction Engineering; Springer International Publishing: Cham, Switzerland, 2019; pp. 725-731.

8. Kibert, C.J. The next generation of sustainable construction. Build. Res. Inf. 2007, 35, 595-601. [CrossRef]

9. Lacy, P.; Rutqvist, J. Waste to Wealth: The Circular Economy Advantage. Palgrave Macmillan: London, UK, 2016.

10. Conejos, S.; Langston, C.; Smith, J. Designing for better building adaptability: A comparison of adaptSTAR and ARP models. Habitat Int. 2014, 41, 85-91. [CrossRef]

11. UN Environment and International Energy Agency. Towards a Zero-Emission, Efficient, and Resilient Buildings and Construction Sector; Global Alliance for Buildings and Construction (GABC): Paris, France, 2017.

12. Unalan, B.; Tanrivermis, H.; Bulbul, M.; Celani, A.; Ciaramella, A. Impact of embodied carbon in the life cycle of buildings on climate change for a sustainable future. Int. J. Hous. Sci. Its Appl. 2018, 40, 61-71.

13. World Economic Forum. Shaping the Future of Construction: A Breakthrough in Mindset and Technology; Cologny: Geneva, Switzerland, 2016.

14. Sassi, P. Defining closed-loop material cycle construction. Build. Res. Inf. 2008, 36, 509-519. [CrossRef]

15. Jaillon, L.; Poon, C.S. Life cycle design and prefabrication in buildings: A review and case studies in Hong Kong. Autom. Constr. 2014, 39, 195-202. [CrossRef]

16. Schultmann, F.; Sunke, N. Energy-oriented deconstruction and recovery planning. Build. Res. Inf. 2007, 35, 602-615. [CrossRef]

17. Silvestre, J.D.; de Brito, J.; Pinheiro, M.D. Environmental impacts and benefits of the end-of-life of building materials-Calculation rules, results and contribution to a "cradle to cradle" life cycle. J. Clean. Prod. 2014, 66, 37-45. [CrossRef]

18. Gorgolewski, M. Designing with reused building components: Some challenges. Build. Res. Inf. 2008, 36, 175-188. [CrossRef]

19. Guy, B.; McLendon, S. Building Deconstruction: Reuse and Recycling of Building Materials. Center for Construction and Environment, Report to the Florida Department of Environmental Protection: Gainesville, USA, 2000.

20. Kokkos, A. Computational Modelling Tools for the Promotion of Design for Deconstruction. Master's Thesis, Delft University of Technology, Delft, Netherlands, 2014.

21. Sanchez, B.; Haas, C. A novel selective disassembly sequence planning method for adaptive reuse of buildings. J. Clean. Prod. 2018, 183, 998-1010. [CrossRef]

22. Volk, R.; Luu, T.H.; Mueller-Roemer, J.S.; Sevilmis, N.; Schultmann, F. Deconstruction project planning of existing buildings based on automated acquisition and reconstruction of building information. Autom. Constr. 2018, 91, 226-245. [CrossRef]

23. Yeung, J. Development of Analysis Tools for the Facilitation of Increased Structural Steel Reuse. Ph.D. Thesis, University of Waterloo, Waterloo, ON, Canada, 2016.

24. Douglas, J. Building Adaptation; Butterworth-Heinemann: London, UK, 2002.

25. Langston, C.A. The sustainability implications of building adaptive reuse. In Proceedings of the CRIOCM 2008 International Research Symposium on Advancement of Construction Management and Real Estate, Beijing, China, 31 October-3 November 2008.

26. Bullen, P.A. Adaptive reuse and sustainability of commercial buildings. Facilities 2007, 25, 20-31. [CrossRef]

27. Smith, S.; Hung, P.-Y. A novel selective parallel disassembly planning method for green design. J. Eng. Des. 2015, 26, 283-301. [CrossRef]

28. Conejos, S.; Chew, M.Y.L.; Yung, E.H.K. The future adaptivity of nineteenth century heritage buildings. Int. J. Build. Pathol. Adapt. 2017, 35, 332-347. [CrossRef]

29. Langston, $\mathrm{C}$. The role of coordinate-based decision-making in the evaluation of sustainable built environments. Constr. Manag. Econ. 2013, 31, 62-77. [CrossRef] 
30. Ortlepp, R.; Gruhler, K.; Schiller, G. Material stocks in Germany's non-domestic buildings: A new quantification method. Build. Res. Inf. 2016, 44, 840-862. [CrossRef]

31. Stephan, A.; Athanassiadis, A. Quantifying and mapping embodied environmental requirements of urban building stocks. Build. Environ. 2017, 114, 187-202. [CrossRef]

32. Viscusi, W. Monetizing the Benefits of Risk and Environmental Regulation. Fordham Urban Law J. 2006, 33, 1003. [CrossRef]

33. Lyngsgaard, S.; Jorgensen, K.G. Cradle to Cradle ${ }^{\circledR}$ _In the Built Environment: A Manual for the Danish Building Industry; Vugge Til Vugge Danmark and GXN with Support from Realdania, Gugler: Copenhagen, Danmark, 2013.

34. Sanchez, B.; Haas, C. Methodology for improving the net environmental impacts of new buildings through product recovery management. In Proceedings of the 6th CSCE/CRC International Construction Specialty Conference, Vancouver, BC, Canada, 31 May-3 June 2017.

35. Atakul, N.; Thaheem, M.J.; De Marco, A. Risk management for sustainable restoration of immovable cultural heritage, part 1: PRM framework. J. Cult. Herit. Manag. Sustain. Dev. 2014, 4, 149-165. [CrossRef]

36. Nwachukwu, C.V.; Udeaja, C.; Chileshe, N.; Okere, C.E. The critical success factors for stakeholder management in the restoration of built heritage assets in the UK. Int. J. Build. Pathol. Adapt. 2017, 35, 304-331. [CrossRef]

37. Highfield, D.; Gorse, C. Refurbishment and Upgrading of Buildings; Spon Press: London, UK, 2014.

38. Construction Industry Institute. Interface Management Implementation Guide; The University of Texas at Austin: Austin, TX, USA, 2014.

39. Chua, D.K.H.; Godinot, M. Use of a WBS matrix to improve interface management in projects. J. Constr. Eng. Manag. 2006, 132, 67-79. [CrossRef]

40. Stuckenbruck, L.C. Integration: The Essential Function of Project Management. In Project Management Handbook; John Wiley \& Sons, Inc.: NJ, USA, 2008; pp. 56-81.

41. Shokri, S.; Haas, C.; Haas, G.R.; Lee, S. Interface-Management Process for Managing Risks in Complex Capital Projects. J. Constr. Eng. Manag. 2016, 142, 4015069. [CrossRef]

42. Pavitt, T.C.; Gibb, A.G.F. Interface management within construction: In particular, building façade. J. Constr. Eng. Manag. 2003, 129, 8-15. [CrossRef]

43. Shokri, S. Interface Management for Complex Capital Projects. Ph.D. Thesis, University of Waterloo, Waterloo, ON, Canada, 2014.

44. Chen, Q.; Reichard, G.; Beliveau, Y. Multiperspective approach to exploring comprehensive cause factors for interface issues. J. Constr. Eng. Manag. 2008, 134, 432-441. [CrossRef]

45. Lin, Y.-C. Construction network-based interface management system. Autom. Constr. 2013, 30, $228-241$. [CrossRef]

46. Ju, Q.Q.; Ding, L.Y. A Web-Based System for Interface Management of Metro Equipment Engineering. J. Intell. Robot. Syst. Theory Appl. 2015, 79, 577-590. [CrossRef]

47. Lin, Y.-C. Use of BIM approach to enhance construction interface management: A case study. J. Civ. Eng. Manag. 2015, 21, 201-217. [CrossRef]

48. Eray, E.; Golzarpoor, B.; Rayside, D.; Haas, C. An Overview on Integrating Interface Management and Building Management Systems. In Proceedings of the 6th CSCE/CRC International Construction Specialty Conference, Vancouver, BC, Canada, 31 May-3 June 2017.

49. Shokri, S.; Safa, M.; Haas, C.T.; Haas, R.C.G. A conceptual framework to improve information and process management in the execution of capital projects. In Proceedings of the Annual Conference-Canadian Society for Civil Engineering, Ottawa, ON, Canada, 14-17 June 2011; pp. 2409-2418.

50. Shokri, S.; Safa, M.; Haas, C.T.; Haas, R.C.G.; Maloney, K.; MacGillivray, S. Interface Management Model for Mega Capital Projects. In Proceedings of the Construction Research Congress 2012: Construction Challenges in a Flat World, West Lafayette, IN, USA, 21-23 May 2012; pp. 447-456.

51. Shokri, S.; Ahn, S.; Lee, S.; Haas, C.; Haas, R. Current Status of Interface Management in Construction: Drivers and Effects of Systematic Interface Management. J. Constr. Eng. Manag. 2016, 142, 4015070. [CrossRef]

52. Hein, M.F.; Houck, K.D. Construction Challenges of Adaptive Reuse of Historical Buildings in Europe. Int. J. Constr. Educ. Res. 2008, 4, 115-131. [CrossRef]

53. Conejos, S.; Langston, C.; Chan, E.H.W.; Chew, M.Y.L. Governance of heritage buildings: Australian regulatory barriers to adaptive reuse. Build. Res. Inf. 2016, 44, 507-519. [CrossRef] 
54. Al-Hammad, A.-M. Study of the interface problems between owners and contractors over the construction of residential houses in Saudi Arabia. Int. J. Hous. Sci. Its Appl. 1990, 14, 245-257.

55. Al-Hammad, A.; Assaf, S. Design-Construction interface problems in Saudi Arabia. Build. Res. Inf. 1992, 20, 60-63. [CrossRef]

56. Al-Hammad, A. Factors affecting the relationship between contractors and their sub-contractors in Saudi Arabia. Build. Res. Inf. 1993, 21, 269-273. [CrossRef]

57. Al-Hammad, A.-M. Interface Problems between Owners and Maintenance Contractors in Saudi Arabia. J. Perform. Constr. Facil. 1995, 9, 194-205. [CrossRef]

58. Al-Hammad, A.-M.; Al-Hammad, I. Interface Problems between Building Owners and Designers. J. Perform. Constr. Facil. 1996, 10, 123-126. [CrossRef]

59. Al-Mansouri, O.H. The relationship between the designer and the contractor in Saudi Arabia. Ph.D. Thesis, University of Reading, Reading, UK, 1988.

60. Hinze, J.; Tracey, A. The Contractor-Subcontractor Relationship: The Subcontractor's View. J. Constr. Eng. Manag. 1994, 120, 274-287. [CrossRef]

61. Al-Hammad, A.-M. Common Interface Problems among Various Construction Parties. J. Perform. Constr. Facil. 2000, 14, 71-74. [CrossRef]

62. Arain, F.; Assaf, S. Consultant's Prospects of the Sources of Design and Construction Interface problems in Large Building Projects in Saudi Arabia. J. King Abdulaziz Univ. Des. Sci. 2007, 5, 15-37. [CrossRef]

63. Sha'ar, K.Z.; Assaf, S.A.; Bambang, T.; Babsail, M.; Fattah, A.M.A. Design-construction interface problems in large building construction projects. Int. J. Constr. Manag. 2017, 17, 238-250. [CrossRef]

64. AL Mousli, M.H.; El-Sayegh, S.M. Assessment of the design-construction interface problems in the UAE. Archit. Eng. Des. Manag. 2016, 12, 353-366. [CrossRef]

65. Vanegas, J.A.; Opdenbosch, A. Using simulation and visualization technologies to strengthen the design/construction interface. In Proceedings of the Winter Simulation Conference, Lake Buena Vista, FL, USA, 11-14 December 1994; pp. 1137-1144.

(C) 2019 by the authors. Licensee MDPI, Basel, Switzerland. This article is an open access article distributed under the terms and conditions of the Creative Commons Attribution (CC BY) license (http://creativecommons.org/licenses/by/4.0/). 